\title{
Effect of Free-Choice Feeding on the Performance and Ileal Digestibility of Nutrients in Broilers
}

-Author(s)
Cruz VC
Pezzato AC
Pinheiro DF
Gonçalves JC
Sartori JR
Universidade Estadual Paulista
Faculdade de Medicina Veterinária e
Zootecnia
Departamento de Melhoramento e Nutrição
Animal
18.618-000. Botucatu, SP, Brasil
Phone 551438117187

\section{Mail Address}

Valquiria Cação da Cruz

UNESP - Depto de Melhoramento e Nutrição Animal

Faculdade de Medicina Veterinária e Zootecnia Fazenda Experimental Lageado s/n

Caixa Postal 560

18.618-000. Botucatu, SP, Brazil

Phone 551438117187

E-mail: valzootec@fca.unesp.br

\section{Keywords}

Broiler, digestibility coefficient, free-choice feeding, performance.

\section{ABSTRACT}

An experiment was conducted to study ileal digestibility of nutrients and to verify the ability of broilers to select feed in order to meet their requirements for protein and energy. The treatments consisted of six diets: $R+S$ : free-choice feeding with rice bran (energy) and soybean meal (protein); $C+G$ : free-choice feeding with corn (energy) and corn gluten meal (protein); $\mathrm{R}+\mathrm{G}$ : free-choice feeding with rice bran (energy) and corn gluten meal (protein); $C+S$ : free-choice feeding with corn (energy) and soybean meal (protein); $\mathrm{R}+\mathrm{C}+\mathrm{G}+\mathrm{S}$ : free-choice feeding with rice bran and corn (energy) and corn gluten meal and soybean meal (protein); and BD: basal diet represented by a complete diet composed of $63 \%$ corn and $33 \%$ soybean meal. The results indicated that the adjustment to nutritional requirements does not depend only on the ability of birds to select feed. It might also depend on intake and ingredient quality, since some ingredients did not provide a balanced amount of nutrients. The birds were able to fulfill their requirements for maintenance, that is, they consumed the minimum amount of amino acids (g per day) for maximum growth. The free-choice group with corn gluten meal as the protein source had the worst performance, which indicated that this feed is not recommended as a primary source of amino acids for broilers. The $C+G$ diet presented the highest digestibility coefficient of dry matter and crude protein, whereas the $\mathrm{C}+\mathrm{S}$ diet resulted in the highest digestibility coefficient of ether extract and nitrogen-free extract, indicating that diet digestibility was affected by the type of feed used as energy and protein sources. In general, the high digestibility values indicate that broilers are able to efficiently digest and absorb the supplied feed.

\section{INTRODUCTION}

It is known that poultry, as well as other animals, adjust their voluntary intake of feed to maintain appropriate daily intake when offered diets with different energy and protein densities. Under natural or experimental conditions, chickens eat different feedstuffs that are individually incomplete, so that the challenge consists in evaluating all the available feedstuffs and selecting an adequate diet from them.

The cafeteria method, or free-choice feeding, allows the animal to formulate its own diet, selecting the feeds based on the requirements for maintenance and production, which may increase efficiency when compared to complete diets. Producers with little experience adapt well to this system, which is labor-saving and offers good results in breeding programs for high production (Oliveira, 1999).

It is necessary to know which factors might influence the selection of the diet by the bird under a free-choice situation. Emmans (1978) 
Cruz VC, Pezzato AC, Pinheiro DF, Gonçalves JC, Sartori JR

Effect of Free-Choice Feeding on the Performance and Ileal Digestibility of Nutrients in Broilers cited by Yo et al. (1997) suggested that feed intake in a choice situation depends on the nutrient requirements of the animal and feed composition, which also takes into consideration sensory characteristics of diets such as color, smell, taste and texture that are not related to nutrient composition. However, these sensory factors may have key roles in nutrient intake and regulation of intake.

A considerable number of cafeteria-type studies have been conducted in the last century. Most of them reported that chickens were able to self-select nutrients in proportions adequate to sustain normal or near normal growth (Kaufman et al., 1978).

Theoretically, variations in feed intake can influence apparent nutrient digestibility, either by altering the relative contribution of exogenous material to the total digesta or by influencing transit time of ingested feed (Cherry \& Siegel, 1978).

The assessment of the nutritional value of feeds consumed by animals has always challenged nutritionists. Since not every feed is digested and absorbed efficiently, the assessment of the nutritional value of ingredients has been and continues to be an important issue in the poultry industry. Thus, a good indicator of how an animal can process and absorb nutrients from a given diet is the determination of nutrient digestibility (Angel, 1993), which is obtained by comparing the amount of nutrient that is ingested and the amount that is excreted in faeces.

In chickens, the concomitant excretion of faeces and urine and its consequences for determination of digestibility has prompted the development of the ileal method. The use of ileal digestibility data is explained because the estimation of nutrient digestibility by means of excreta analysis might be diversely affected by microbial fermentation (Raharjo \& Farrell, 1984; Johnson, 1992; Farrell et al., 1999).

Thus, the purpose of the present study was to determine dietary selectivity of broilers when different energy and protein feed sources are available and the apparent ileal digestibility of these nutrients.

\section{MATERIALS AND METHODS}

The experiment was conducted at the Poultry Nutrition Laboratory of the Faculdade de Medicina Veterinária e Zootecnia in Botucatu, SP. Three hundred and sixty-four one-day-old male broilers (Ross) were housed in a metal brooding battery with 5 floors and 6 cages per floor, at an initial density of 12 broilers per cage.
The broilers were distributed in 6 experimental groups and 5 blocks (floors of the battery) to evaluate the self-regulation of ingestion of protein and energy in a dietary free choice system (cafeteria system), using the following dietary treatments: R+S: rice bran (energy) and soybean meal (protein); $C+G$ : corn (energy) and corn gluten meal (protein); $\mathrm{R}+\mathrm{G}$ : rice bran (energy) and corn gluten meal (protein); $C+S$ : corn (energy) and soybean meal (protein); $\mathrm{R}+\mathrm{C}+\mathrm{G}+\mathrm{S}$ : rice bran and corn (energy), and corn gluten meal and soybean meal (protein) and BD: basal diet formulated with 63\% corn and 33\% soybean meal, according to Rostagno et al. (2000) recommendations (Table 1). The feeds were presented in mash form. The birds under free-choice feeding also had access to a supplement source (Table 2 ).

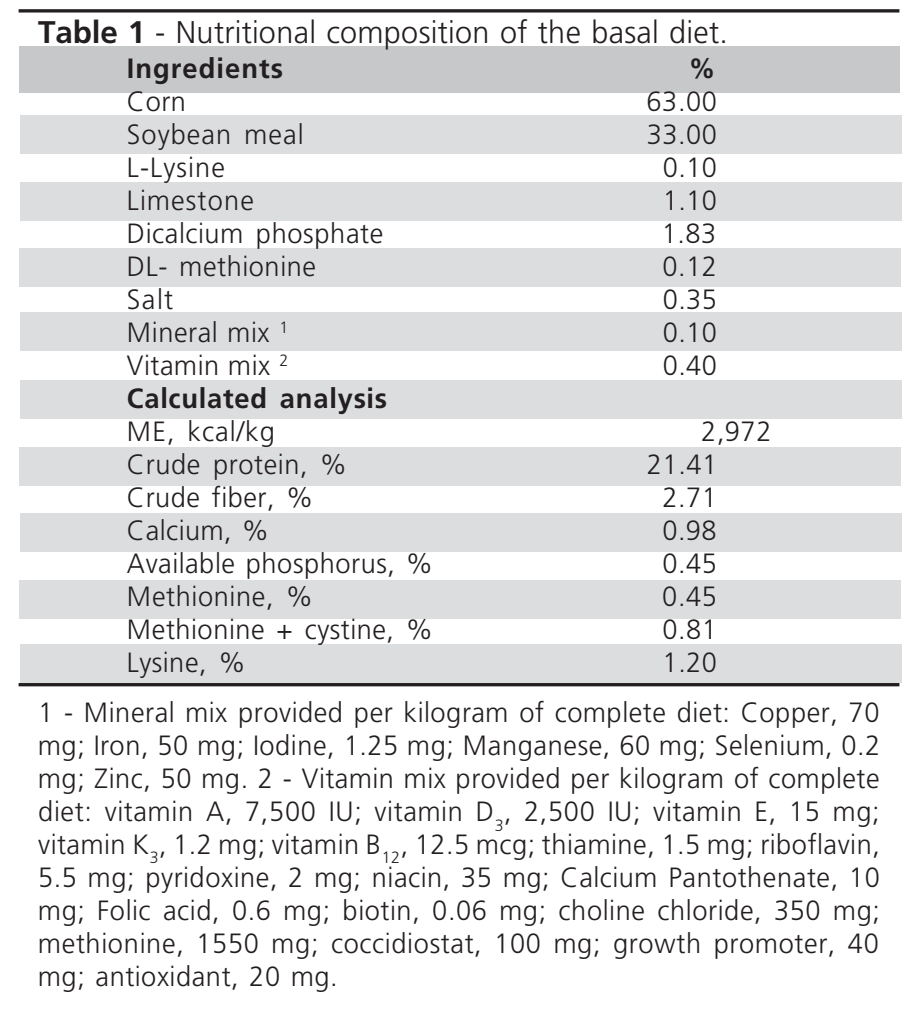

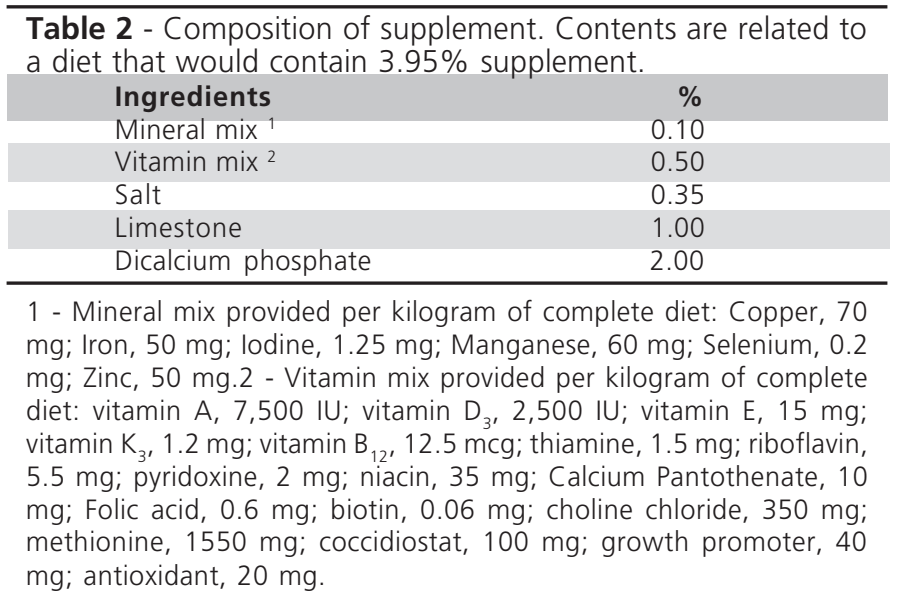


Cruz VC, Pezzato AC, Pinheiro DF, Gonçalves JC, Sartori JR

Nipple drinkers provided water ad libitum. Feeding troughs were equipped with 3 compartments to separate the sources of energy, protein and the supplement, with the exception of the 5-compartment feeder of treatment $\mathrm{R}+\mathrm{C}+\mathrm{G}+\mathrm{S}$. The proportion of each feed in each compartment was $70 \%$ of energy feed and $30 \%$ of protein feed, approximately.

Two feeder types were used, with increasing sizes according to the age of the birds. The feeders were coupled to wooden trays with similar divisions in order to collect the feed that was wasted during feeding. The amount of each type of feed that was collected (energy, protein or supplement) was subtracted in the calculation of feed intake, in order to express the actual intake of the birds.

The following parameters were evaluated: feed intake (I), weight gain (WG), feed conversion (FC), energy conversion ( $E C)$, protein conversion ( $P C)$, conversion of amino acids and mortality.

On the $25^{\text {th }}$ day of the experiment, $0.1 \%$ chromium oxide $\left(\mathrm{Cr}_{2} \mathrm{O}_{3}\right)$ was added in each compartment as an inert marker. On the $30^{\text {th }}$ day, one bird was killed per cage and the ileum removed. Samples of digesta were taken from the ileum close to the Meckel's diverticulum halfway along the small intestine, immediately frozen at $-18^{\circ} \mathrm{C}$ and stored until analysis. Subsequently the samples were dried and ground. The calculations of digestibility from marker concentrations were carried out using the equation of Schneider \& Flat (1975).

The digestibility coefficients of dry matter (DM), crude protein $(C P)$, ether extract (EE) and nitrogen-free extract (NFE) were determined according to the procedure of WEENDE, as recommended by the Association of Official Analytical Chemists (AOAC, 1990).

The levels of chromium oxide in the ingredients, the control diet and fecal samples were determined by the method proposed by Bremer (1999).
Effect of Free-Choice Feeding on the Performance and Ileal Digestibility of Nutrients in Broilers

A completely randomized block design was used with 5 replicates for performance variables and 4 replicates for variables of digestibility.

Statistical analyses of performance and apparent ileal digestibility data were performed using the General Linear Models procedure for analysis of variance (SAS Institute, 1996). Significant differences among treatment means were separated by the Tukey's test at $5 \%$ of significance.

\section{RESULTS}

Table 3 shows the means for feed intake (I), weight gain (WG), feed conversion ( $F C$ ), energy conversion (EC) and protein conversion (PC) in broilers up to 30 days of age. There were differences $(p<0.05)$ among the treatments for all variables. The block effect (floors of the battery) had no influence on these variables, except for feed intake $(p<0.05)$.

Intake was greater in birds fed the balanced diet, differing $(p<0.05)$ from the other treatments. Feed intake was not statistically different ( $p>0.05)$ among the treatments $R+S, C+S$ and $R+C+G+S$. These diets with soybean meal as the protein source presented a better balance of essential amino acids. Diets $C+G$ and $R+G$, although different $(p<0.05)$, provided the smallest intakes, probably because the protein source of these diets (corn gluten meal) presented an unbalance of essential amino acids.

Weight gain (WG) directly reflected feed intake in all treatments, and was approximately $29.24 \%(R+S)$, 96.03\% $(C+G), 82.78 \%(R+G), 33.84 \%(C+S)$ and $26.13 \%(R+C+G+S)$ lower than the WG of chickens fed the complete diet.

Feed conversion $(F C)$ was different $(p<0.05)$ between treatments $C+G$ and $R+G$, which were also different from the other treatments. The poorest $\mathrm{FC}$ (5.40) was obtained with the treatment $C+G$ and the

\begin{tabular}{|c|c|c|c|c|c|}
\hline Treatments $^{1}$ & $\begin{array}{l}\text { Feed Intake } \\
\text { (g/broiler) }\end{array}$ & $\begin{array}{l}\text { Weight Gain } \\
\text { (g) }\end{array}$ & $\begin{array}{l}\text { Feed Conversion } \\
\text { (g feed/g WG) }\end{array}$ & $\begin{array}{c}\text { Energy Conversion } \\
\text { (Mcal/g WG) }\end{array}$ & $\begin{array}{l}\text { Protein Conversion } \\
\text { (g CP/g WG) }\end{array}$ \\
\hline $\mathrm{R}+\mathrm{S}$ & $1578.56 \pm 108.24^{b}$ & $821.59 \pm 57.69 b$ & $1.93 \pm 0.18 \mathrm{~cd}$ & $4.50 \pm 0.44$ & $0.62 \pm 0.08$ \\
\hline $\mathrm{C}+\mathrm{G}$ & $247.91 \pm 7.39$ d & $46.11 \pm 3.85^{d}$ & $5.40 \pm 0.43^{a}$ & $17.73 \pm 1.39$ & $0.65 \pm 0.07 a$ \\
\hline$R+G$ & $621.99 \pm 59.61^{c}$ & $199.99 \pm 17.42^{c}$ & $3.11 \pm 0.08^{b}$ & $7.51 \pm 0.15 b$ & $0.51 \pm 0.06^{b}$ \\
\hline$C+S$ & $1602.22 \pm 218.43^{b}$ & $768.15 \pm 132.45^{b}$ & $2.10 \pm 0.14^{c}$ & $6.30 \pm 0.44^{c}$ & $0.45 \pm 0.02 b$ \\
\hline$R+C+G+S$ & $1616.08 \pm 220.41^{b}$ & $857.66 \pm 137.29 b$ & $1.89 \pm 0.14^{\mathrm{cd}}$ & $5.70 \pm 0.48^{c d}$ & $0.49 \pm 0.04^{b}$ \\
\hline $\mathrm{BD}$ & $1972.03 \pm 44.85^{a}$ & $1161.05 \pm 25.57$ & $1.70 \pm 0.07^{d}$ & $5.05 \pm 0.20 \mathrm{de}$ & $0.37 \pm 0.01 c$ \\
\hline $\mathrm{CV}^{2}(\%)$ & 9.06 & 12.21 & 7.63 & 8.38 & 10.72 \\
\hline
\end{tabular}

1 - R+S - rice bran, soybean meal, premix; $C+G$ - corn, corn gluten meal, premix; $R+G$ - rice bran, corn gluten meal, premix; $C+S$ - corn, soybean meal, premix; $R+C+G+S$ - rice bran, corn, corn gluten meal, soybean meal, premix; BD - basal diet based on corn and soybean meal. 2 - $C V$ Coefficient of variation. Weight gain= mean final weight - mean initial weight; Feed conversion ratio= total feed intake (grams)/ mean weight gain (grams); Energy conversion = ME intake (Mcal)/ mean weight gain (grams); Protein conversion = crude protein intake (grams)/ mean weight gain (grams). Means within columns with common superscripts do not differ significantly by the test of Tukey ( $p>0.05$ ). 
Cruz VC, Pezzato AC, Pinheiro DF, Gonçalves JC, Sartori JR

Effect of Free-Choice Feeding on the Performance and Ileal Digestibility of Nutrients in Broilers best FC (1.70) was shown by the birds that received the balanced diet.

In addition, the free-choice feeding system affected the efficiency of utilization of the ingested feed, i.e., the values of energy conversion (EC), expressed as Mcal of $M E$ per gram of $W G$, and protein conversion (PC), expressed as grams of CP per gram of WG. Treatment $C+G$ showed a well-differentiated $E C$ in relation to the other treatments; it did not fit the expected patterns and might be considered an outlier in comparison to other treatment means (5.81 Mcal ME/g WG). The birds fed the balanced diet presented EC statistically similar to the treatments $\mathrm{R}+\mathrm{C}+\mathrm{G}+\mathrm{S}$ and $\mathrm{R}+\mathrm{S}$, which were different $(p<0.05)$ from each other. The birds fed with the balanced diet showed the best PC $(0.37 \mathrm{~g}$ (P/ g WG), significantly different from the other treatments. Treatments $R+G, C+S$ and $R+C+G+S$ showed intermediate $P C$ values which did not differ from each other, whereas treatments $R+S$ and $C+G$ showed the worst rates of protein conversion.

Concerning amino acid conversion in relation to weight gain (Table 4), the basal diet showed better results. The conversion of tryptophan and lysine of the basal diet was similar to conversion of diets $C+G, R+G$ and $R+C+G+S$, whereas the conversion of methionine and methionine + cystine of the basal diet was similar to that of diets $C+S$ and $R+C+G+S$. Thus, the birds fed these diets were able to convert the amino acids as efficiently as the birds fed with basal diet.

No differences were found among the treatments for mortality rate, which was approximately $2 \%$ in this study.

The results of the effects of different feed sources on the apparent ileal digestibility coefficient (DCileal) of the experimental diets are presented in Table 5.

For the ileal dry matter digestibility coefficient (DMDC), the treatments that contained rice bran as the main energy source showed similar values, that were different $(p<0.05)$ from those with corn as the main energy source, which were also similar among them. Therefore, these results evidence that ileal digestibility was affected by the use of different energy sources.

Crude protein digestibility coefficients (CPDC) were lower in $\mathrm{R}+\mathrm{S}$ and $\mathrm{BD}$ diets than in other treatments, although similar to the treatment $\mathrm{R}+\mathrm{C}+\mathrm{G}+\mathrm{S} . \mathrm{C}+\mathrm{G}$ and $C+S$ diets presented higher $D C$ ileal values for $C P$, which were similar to the treatment $R+G$.

The analysis of the digestibility coefficients of ether extract (EE) and nitrogen-free extract (NFE) of the R+G diet showed a similar behavior, indicating the smallest digestibility in relation to the other treatments. The birds

\begin{tabular}{|c|c|c|c|c|c|}
\hline \multirow[t]{2}{*}{ Treatments ${ }^{1}$} & \multicolumn{5}{|c|}{ Amino acids $^{3}$} \\
\hline & Trp & Thr & Met & Met+Cys & Lys \\
\hline$R+S$ & $0.82 \pm 0.11$ & $2.39 \pm 0.30^{a}$ & $0.89 \pm 0.11 b c$ & $1.85 \pm 0.23 b$ & $3.60 \pm 0.47$ a \\
\hline$C+G$ & $0.40 \pm 0.04 c$ & $2.43 \pm 0.25^{a}$ & $1.39 \pm 0.16^{a}$ & $2.78 \pm 0.30^{a}$ & $1.60 \pm 0.14^{c}$ \\
\hline$R+G$ & $0.45 \pm 0.01 c$ & $1.84 \pm 0.19 b$ & $1.00 \pm 0.15^{b}$ & $1.87 \pm 0.25^{b}$ & $1.80 \pm 0.04 c$ \\
\hline$C+S$ & $0.54 \pm 0.03 b$ & $1.76 \pm 0.09 b$ & $0.70 \pm 0.04 c$ & $1.47 \pm 0.08^{c}$ & $2.38 \pm 0.12^{b}$ \\
\hline$R+C+G+S$ & $0.50 \pm 0.04^{c}$ & $1.86 \pm 0.16^{b}$ & $0.86 \pm 0.10^{c}$ & $1.70 \pm 0.17^{c}$ & $2.14 \pm 0.16^{c}$ \\
\hline $\mathrm{BD}$ & $0.44 \pm 0.02 c$ & $1.41 \pm 0.06^{c}$ & $0.76 \pm 0.03 c$ & $1.38 \pm 0.05^{c}$ & $2.04 \pm 0.08^{c}$ \\
\hline$C V^{2}(\%)$ & 10.22 & 10.10 & 11.31 & 10.41 & 10.32 \\
\hline
\end{tabular}

1 - $R+S$ - rice bran, soybean meal, premix; $C+G$ - corn, corn gluten meal, premix; $R+G$ - rice bran, corn gluten meal, premix; $C+S$ - corn, soybean meal, premix; $R+C+G+S$ - rice bran, corn, corn gluten meal, soybean meal, premix; BD - complete ration based on corn and soybean meal. 2 - $C V$ - Coefficient of variation. 3 - Trp - Tryptophan; Thr - Threonine; Met - Methionine; Met+Cys - Methionine + Cystine; Lys - Lysine.Amino acid conversion $=$ Total feed or ration intake (grams) $\times$ \% respective amino acid/ weight gain (grams). Means within columns with common superscripts do not differ significantly by the test of Tukey $(p>0.05)$.

\begin{tabular}{|c|c|c|c|c|}
\hline Treatments $^{1}$ & DM, \% & $\mathrm{CP}, \%$ & EE, \% & NFE, \% \\
\hline $\mathrm{R}+\mathrm{S}$ & $87.35 \pm 2.89 b$ & $93.84 \pm 2.28^{c}$ & $91.66 \pm 1.98 b c$ & $87.39 \pm 2.14^{b}$ \\
\hline$C+G$ & $92.67 \pm 1.44^{a}$ & $97.94 \pm 0.10^{a}$ & $94.60 \pm 0.93^{a}$ & $89.62 \pm 3.32 a b$ \\
\hline$R+G$ & $87.14 \pm 2.05^{b}$ & $96.57 \pm 0.36 a b$ & $91.03 \pm 1.80^{c}$ & $82.34 \pm 3.72^{c}$ \\
\hline$C+S$ & $92.59 \pm 1.66^{a}$ & $96.99 \pm 0.94$ & $94.68 \pm 1.71$ & $92.78 \pm 1.82$ \\
\hline$R+C+G+S$ & $89.13 \pm 1.04^{b}$ & $95.16 \pm 1.31 b c$ & $93.64 \pm 0.45^{a b}$ & $85.51 \pm 1.13 b c$ \\
\hline $\mathrm{BD}$ & $92.28 \pm 0.65^{a}$ & $94.17 \pm 0.34^{c}$ & $93.28 \pm 2.11 \mathrm{abc}$ & $92.49 \pm 1.01^{a}$ \\
\hline $\mathrm{CV}^{2}(\%)$ & 2.13 & 1.25 & 1.79 & 2.91 \\
\hline
\end{tabular}

1 - R+S - rice bran, soybean meal, premix; $C+G$ - corn, corn gluten meal, premix; $R+G$ - rice bran, corn gluten meal, premix; $C+S$ - corn, soybean meal, premix; $R+C+G+S$ - rice bran, corn, corn gluten meal, soybean meal, premix; BD - basal diet based on corn and soybean meal. 2 - CV Coefficient of variation. DM- Dry matter; CP- Crude protein; EE- Ether extract; NFE- Nitrogen-free extract.Means within columns with common superscripts do not differ significantly by the test of Tukey $(p>0.05)$. 
Cruz VC, Pezzato AC, Pinheiro DF, Gonçalves JC, Sartori JR

fed basal diet (BD) showed intermediate levels of ether extract digestibility coefficient, which was not significantly different from the other treatments.

\section{DISCUSSION}

The balanced complete diet offered as the basal diet (BD) was consumed more thoroughly in terms of supplying appropriate amounts of nutrients. Comparing the intake of protein sources in all treatments, a clear preference for soybean meal was observed (Table 6), which may be due to the fact that soybean meal provides a better balance of essential amino acids (Rostagno et al., 2000).

When comparing the diets $C+G$ and $R+G$, both of which contained corn gluten meal, it was observed that the intake and consequently the weight gain were higher in the latter. This result might be due to the superior biological value of the protein of rice bran relative to that of corn and also its CP content $(13.21 \%)$ compared with corn (8.57\%) (Rostagno et al., 2000). The weight gain of birds fed $\mathrm{C}+\mathrm{G}$ or $\mathrm{R}+\mathrm{G}$ was much lower mainly because corn gluten meal is less palatable and has low biological value, that is, birds do not efficiently use the nutrients provided by corn gluten meal.

Corn gluten meal is a commodity of corn, from which most of the starch and germ have been removed, resulting in limited lysine and tryptophan levels. Although the protein content of this ingredient may be as high as $60 \%$, the low quality is a determining factor in reducing the consumption by birds. Waldroup et al. (1976) observed that birds tend to decrease the intake of feeds that contain higher levels of energy, resulting in reduced intake of protein and other nutrients. Similarly, Forbes \& Shariatmadari (1994) affirmed that when only one feed is available, intake is determined predominantly by its energy content; however, when two feeds are offered, the intake of each nutrient can be controlled independently. According to the same authors, energy and protein are the most important dietary components in
Effect of Free-Choice Feeding on the Performance and Ileal Digestibility of Nutrients in Broilers

commercial diets. Although readily available feeds show a wide range of protein levels (from around 80 $\mathrm{g} / \mathrm{kg}$ for maize to $600 \mathrm{~g} / \mathrm{kg}$ for fish meal), the range of energy levels is quite limited (3370 to $2670 \mathrm{kcal}$ metabolizable energy/kg, respectively). Therefore, the selection between two feeds is based most likely on the protein content (Forbes \& Shariatmadari, 1994).

In chickens, the yolk sac is the major nutritional source during the first days of life, so that the requirement of nutrients coming from the diet is more important in the following days and weeks. Thus, the evolution of a feeding pattern might be dependent on the feed requirements that are increasing with age (Hale \& Green, 1988). Moreover, birds have a lower choice capacity when using the sensory organs in the first days of life (Pond et al., 1995). The more developed sensory system after the second week of age allowed the birds to select the ingredients based not only on the attractiveness, but also on the need to fulfill nutritional requirements. In those treatments in which corn gluten meal was used as the protein source $(C+G$ and $R+G)$, intake was the lowest possible since the birds were still using the yolk sac reserves and it is also possible that they rejected the feed due to the low palatability and strong smell.

The birds submitted to the treatment $\mathrm{R}+\mathrm{C}+\mathrm{G}+\mathrm{S}$ showed a preference for corn and soybean meal throughout the experiment. In the beginning, intake was preferably for protein sources (soybean meal + corn gluten meal) and at the end of the experiment intake was preferably for the energy source (corn). The availability of a second protein source (corn gluten meal) demonstrated clearly the ability of the birds of this treatment to self select protein and energy sources to meet nutritional requirements. Furthermore, it was clear in this treatment that besides corn and soybean meal, other energy and protein sources might be included in the formulation of the diet to help to balance the ration and to reduce costs.

Some previous studies have shown no differences between complete feeding systems and free choice

\begin{tabular}{|c|c|c|c|c|c|}
\hline Treatments $^{1}$ & Rice Bran & Soybean Meal & Corn & Maize Gluten Meal 60 & Supplement \\
\hline $\mathrm{R}+\mathrm{S}$ & $36.58 \pm 5.02$ & $56.65 \pm 5.14$ & - & - & $6.77 \pm 1.06$ \\
\hline$C+G$ & - & - & $89.09 \pm 1.79$ & $7.37 \pm 1.68$ & $3.54 \pm 0.46$ \\
\hline$R+G$ & $85.00 \pm 4.75$ & - & - & $8.76 \pm 4.38$ & $6.24 \pm 1.38$ \\
\hline$C+S$ & - & $33.35 \pm 1.57$ & $63.90 \pm 1.79$ & - & $2.75 \pm 0.52$ \\
\hline $\mathrm{R}+\mathrm{C}+\mathrm{G}+\mathrm{S}$ & $3.00 \pm 1.19$ & $30.08 \pm 3.84$ & $52.08 \pm 6.58$ & $10.99 \pm 3.43$ & $3.85 \pm 0.95$ \\
\hline
\end{tabular}

1 - R+S - rice bran, soybean meal, premix; C+G - corn, maize gluten meal 60, premix; $R+G$ - rice bran, maize gluten meal 60, pre mix; $C+S$ - corn, soybean meal, premix; $R+C+G+S$ - rice bran, corn, maize gluten meal 60 , soybean meal, premix. 
Cruz VC, Pezzato AC, Pinheiro DF, Gonçalves JC, Sartori JR feeding systems. Nevertheless, most of these studies focused on supplying isoprotein and isocaloric diets or providing most of the essential amino acids through supplementation. The intake of different ingredients observed in the present experiment is in agreement with the results obtained by Sakomura et al. (1997), who tested the conventional feeding system (complete diet) and freechoice feeding system (ground corn or whole grain corn, protein concentrate and oyster). It was concluded that the intake of these ingredients was significantly altered as a function of the feeding systems. The greater corn intake was concomitant with higher intake of protein concentrate, indicating the ability of birds to regulate the intake of ingredients to maintain the energy: protein ratio according to their nutritional requirements. Furthermore, they observed that the birds consumed less protein concentrate than corn. However, these findings differ from those of Mastika (1992) in a similar experiment, who reported no differences in intake as a function of the feeding systems.

Chickens fed the basal diet presented feed intake significantly higher than the chickens in the free choice system. Similar results have been reported in chickens kept under different temperatures and supplied a complete diet or a diet with free choice between wheat and high-protein feed (Cowan \& Michie, 1977).

Rose \& Kyriazakis (1991) offered nine different ingredients to broilers and observed that they were able to select a diet that provided a nutrient intake similar to the requirements published by NRC (National Research Council, 1994). The growth rates of control birds and birds on the free-choice system were similar; whereas the weight gain of choice-fed broilers was approximately $10 \%$ lower than those of birds given complete feeds, results that are different from those reported herein.

The results of conversion of amino acids in relation to weight gain showed that the adjustment to nutritional requirements did not depend only on the ability of birds to choose. It might have also depended on the intake and quality of ingredients, since some of them were not sufficient to meet a balanced requirement. This fact was demonstrated in treatment $C+G$ where birds survived until the end of the experiment consuming enough amounts of methionine (first limiting amino acid) for maintenance but not for growth, and both ingredients supplied in this treatment were poor in lysine (second limiting amino acid) and other amino acids.

The three major limiting amino acids in poultry diets are: lysine, which is involved mainly in protein synthesis;
Effect of Free-Choice Feeding on the Performance and Ileal Digestibility of Nutrients in Broilers

tryptophan, which is a direct precursor of serotonin (a neurotransmitter that interferes with dietary choices); and methionine, which acts in many metabolic pathways including protein synthesis (Larbier \& Leclecq, 1992 mentioned by Picard et al. 1993).

Diets with unbalanced absorption of essential amino acids and amino acid levels lower than the nutritional requirements lead to metabolic disturbances and reduced feed intake. The reduction in feed intake is directly proportional to the degree of amino acid deficiency or unbalance and to a progressive reduction in body weight. This is supposedly due to the metabolic cost involved in the removal of excess amino acids that cannot be utilized because of the relative or absolute deficiency of others. Appetites for individual amino acids can therefore be envisaged if the animal learns that a feed contains lower levels of an amino acid than necessary for its requirements and too much of another. This could happen as long as there were discernible sensory differences between the two feeds to act as cues (Forbes \& Shariatmadari, 1994).

Cockerels of a layer strain were fed two feeds that were individually poorly balanced but complementary in their amino acid composition using alternating periods of 6 or 12 hours (Gous \& DuPreez, 1975, cited by Forbes \& Shariatmadari, 1994). There were no significant differences in feed intake or weight gain either between the two periods or between the control and the diet deficient in amino acids. Thus, it seems that the growing bird has the ability to compensate for short periods on amino acid unbalanced feeds.

Elkin et al. (1985) suggested that regulation of protein intake in choice feeding situations is only possible when the offered diet has adequate sulphur amino acids. The higher intake of protein observed in the non-supplemented group of birds was attributed to the attempt to compensate for the deficiency in amino acids. Despite this deficiency, protein intake tended to decrease throughout the experimental period, a phenomenon that was not observed in the present experiment.

Broilers were given simultaneous access to a balanced diet and another diet deficient in lysine, methionine, and tryptophan in order to evaluate shortterm reactions in a choice situation (Picard et al., 1993). The birds exhibited a marked preference for the balanced diet with a delay of less than 1 to $7 \mathrm{~h}$, which varied according to their previous experience.

The findings in the present study showed that broilers up to 30 days of age in all treatments were able to reach their requirements for maintenance, that 
Cruz VC, Pezzato AC, Pinheiro DF, Gonçalves JC, Sartori JR
Effect of Free-Choice Feeding on the Performance and Ileal Digestibility of Nutrients in Broilers is, they consumed the minimum amount of amino acids (g) per day for maximum growth. This probably means that the first limiting factor was an amino acid and not energy, which does not invalidate the free choice feeding system.

In this type of feeding system, the corn gluten meal is not indicated as the main source of amino acids for birds, since it does not meet the nutritional requirements of the birds on account of its deficiency in essential amino acids.

The high values of ileal digestibility for dry matter, crude protein, ether extract and nitrogen-free extract showed that the birds effectively digested and absorbed the feed supplied, even when intake was low.

The diet $C+G$ presented the highest digestibility coefficients of dry matter and crude protein; the diet $\mathrm{C}+\mathrm{S}$ presented the highest digestibility coefficients of ether extract and nitrogen-free extract, showing that the type of feed adopted as the energy and protein source affects the digestibility of diets.

Dietary proteins are subjected to degradation in the digestive tract both by the digestive enzymes of the animal and by the microflora. The analysis of digesta sampled at the end of the small intestine has therefore become widely regarded as the method of choice for the assessment of the effective absorption of amino acids, in order to estimate the nutritive value of dietary proteins (Fuller et al. 1994).

The present findings corroborate previous studies about the alimentary preference and capacity of birds to balance their intake in order to fulfill nutritional requirements and might serve as basis for subsequent research.

\section{REFERENCES}

Angel RC. Research update: age changes in digestibility of nutrients in ostriches and nutrients profiles status of the hen and chick. $16^{\circ}$ Proceedings of the Association of Avian Veterinarians; 1993. p.27581.

Association of Official Analytical Chemists. $15^{\text {th }}$ ed. Arlington: Official Methods of Analysis; 1990.

Bremer Neto H. O método da S-difenilcarbazida na determinação espectrofotométrica do crômio em fezes, após sua utilização como marcador biológico na forma de óxido de crômio (III) [dissertação]. Botucatu (SP):Universidade Estadual Paulista; 1999.

Cherry JA, Siegel PB. Selection for body weight at eight weeks of age: 15. Feed passage and intestinal size of normal and dwarf chicks. Poultry Science 1978; 57:336-40.
Cowan PJ, Michie W. Environmental temperature and choice feeding of the broiler. British Journal Nutrition 1977; 40:311-5.

Elkin RG, Ndife LI, Rogler JC. Dietary self selection and the regulation of protein and energy intake in chicks. Physiology and Behavior $1985 ; 34: 743-9$.

Farrell DJ, Mannion PF, Perez-Maldonado RA. A comparison of total and digestible amino acids in diets for broilers and layers. Animal Feed and Science Technology 1999; 82:131-42.

Forbes JM, Shariatmadari F. Diet selection for protein by poultry. World's Poultry Science Journal 1994; 50:7-24.

Fuller MF, Darcy-Vrillon B, Laplace JP, Picard M, Cadenhead A, Jung J, Brown D, Franklin MF. The measurement of dietary amino acid digestibility in pigs, rats and chickens: a comparison of methodologies. Animal Feed Science and Technology 1994; 48:305-24

Hale C, Green L. Effects of early ingestional experiences on the acquisition of appropriate feed selection by young chicks. Animal Behaviour 1988; 36:211-24.

Johnson RJ. Principles, problems and aplication of amino acid digestibility in poultry. World's Poultry Science Journal 1992; 48:232-46.

Kaufman LW, Collier G, Squibb RL. Selection of an adequate protein-carbohydrate ratio by the domestic chick. Physiology \& Behavior 1978; 20:339-44.

Mastika IM. Performance of laying hen fed whole corn and protein concentrate free-choice in the tropics. Amsterdam. World's Poultry Congress 1992; 3:623-6.

National Research Council. Nutrient requirements of poultry. $9^{\text {th }}$ ed. rev. Washington (DC): National Academy Press; 1994. p.155.

Oliveira, PMA. Alimentação dos animais monogástricos: suínos, coelhos e aves. 2. ed. São Paulo: Roca; 1999. 245p.

Picard ML, Uzu G, Dunnington EA, Siegel PB. Feed intake adjustments of chicks: short term reactions to deficiencies in lysine, methionine and tryptophan. British Poultry Science 1993; 34:737-46.

Pond K, Church DC, Pond KR. Basic animal nutrition and feeding estimating intake using rare earth markers and controlled release devices. $4^{\text {th }}$ ed. New York: John Wiley \& Sons; 1995.

Raharjo Y, Farrell DJ. A new biological method for determining amino acid digestibility in poultry feedstuffs using a simple cannula, and the influence of dietary fibre on endogenous amino acid output. Animal Feed Science and Technology 1984; 12:29-45.

Rose SP, Kyriazakis I. Diet selection of pigs and poultry. Proceedings of the Nutrition Society 1991; 50:87-98.

Rostagno HS, Albino LFT, Donzele JL, Gomes PC, Ferreira AS, Oliveira RF, Lopes DC. Tabelas brasileiras para aves e suínos: Composição de alimentos e exigências nutricionais. Viçosa (MG): UFV; 2000. $141 p$. 
Cruz VC, Pezzato AC, Pinheiro DF, Gonçalves JC, Sartori JR
Effect of Free-Choice Feeding on the Performance and lleal Digestibility of Nutrients in Broilers

Sakomura NK, Silva R, Moreno SQ, Malheiros EB, Araújo WA, Seixas JRC. Sistemas de alimentação com livre escolha e semi livre escolha para poedeiras. Revista Brasileira de Zootecnia 1997; 26:343-9

Statistical Analysis System. User's guide: statistics, Cary:SAS Institute; 1996.

Schneider BH, Flat WP. The evaluation of feeds through digestibility experiments. Athens: The University of Georgia Press; 1975. 423p.

Waldroup PW, Mitchel RJ, Payne JR, Johnson ZB. Characterization of the response of broiler chickens to diet varying in nutrient density content. Poultry Science 1976, 55:130-45.

Yo T, Siegel PB, Guerin H, Picard M. Self-selection of dietary protein and energy by broilers grown under a tropical climate: Effect of feed particle size on the feed choice. Poultry Science 1997; 76:146773. 